\title{
PENDAMPINGAN PEMBUATAN KANDANG DOMBA SEHAT DI DESA SRIHARJO IMOGIRI KABUPATEN BANTUL
}

\section{Assistance Program to Help Farmers Build Hygienic Sheep Housing in Sriharjo Village Imogiri Subdistrict Bantul District}

\section{Soedarmanto Indarjulianto ${ }^{1)}$, Catur Sugiyanto ${ }^{2)}$, Lilik Soetiarso ${ }^{3)}$, Alva Edy Tontowi ${ }^{4)}$, Ambar Pertiwiningrum ${ }^{5)}$, Teguh Ari Prabowo5), Margaretha Arnita Wuri ${ }^{6)}$}

${ }^{1)}$ Fakultas Kedokteran Hewan, ${ }^{2)}$ Fakultas Ekonomika dan Bisnis, ${ }^{3)}$ Fakultas Teknologi Pertanian ${ }^{4}$ Fakultas Teknik, ${ }^{5}$ Fakultas Peternakan, ${ }^{6}$ Center for Economic Democracy Studies, Universitas Gadjah Mada, Daerah Istimewa Yogyakarta, 55281, Indonesia..

Article history

Received: Aug 17, 2021;

Accepted: Nov 05, 2021

* Corresponding author:

E-mail:

indarjulianto@ugm.ac.id

DOI: https://doi.org/10.465

49/igkojei.v2i3.251

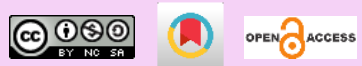

\begin{abstract}
The sheep farming system in Sriharjo village is still under-developed as the animals were housed behind the farmers' house with soil-based floors. This community service aimed to assist the farmers to build a hygienic sheep housing system in Sriharjo village, Imogiri subdistrict, Bantul district. Thirty farmers from Taruna Tani Hijaunya Cinta farmer group, Sriharjo village were taught, trained, participated in a benchmark study, and followed up with supervision during the process of building the hygienic housing system. Questionnaires were used to evaluate the understanding of the farmers before and after the empowerment. The results show the farmers were successfully built the hygienic sheep housing system models. Based on the questionnaire survey, there is an increased understanding percentage about the benefit of the hygienic housing system, from $10 \%$ to $100 \%$ before and after the program, respectively. It can be concluded that the sheep hygiene housing system was established in Sriharjo village and the farmers understand the function.
\end{abstract}

Keywords: Bantul; Hygiene sheep housing; Sheep; Sriharjo.

\section{ABSTRAK}

Ternak domba di Desa Sriharjo masih dipelihara secara tradisional di pekarangan rumah di kandang berlantai tanah. Tujuan dari pengabdian kepada masyarakat ini adalah pendampingan pembuatan kandang domba sehat di Desa Sriharjo, Kecamatan Imogiri, Kabupaten Bantul. Mitra kegiatan pengabdian adalah 30 peternak anggota kelompok ternak Taruna Tani Hijaunya Cinta, desa Sriharjo. Kegiatan yang dilakukan meliputi sosialisasi, pelatihan, studi banding dan dilanjutkan pendampingan peternak membangun kandang sehat. Pemahaman masyarakat terhadap kandang sehat diukur melalui wawancara serta pengisian kuesioner sebelum dan sesudah pengabdian. Hasil pengabdian ini adalah peternak telah berhasil membangun kandang panggung percontohan yang berlokasi di pekarangan yang tidak terlalu dekat dengan rumah penduduk. Hasil survey menunjukkan bahwa sebelum PKM sebanyak 10\% dan setelah PKM semua $(100 \%)$ peternak memahami tentang pengertian dan manfaat kandang sehat. Disimpulkan bahwa kandang domba sehat telah berhasil dibangun dan fungsinya telah dimengerti oleh semua peternak domba di desa Sriharjo.

Kata kunci: Bantul; Domba; Kandang domba sehat; Sriharjo. 


\section{PENDAHULUAN}

Desa Sriharjo merupakan salah satu dari delapan desa yang ada di Kecamatan Imogiri, kabupaten Bantul, yang dibentuk pada tahun 1946. Nama 'Sriharjo' diambil dari geografi wilayah dan mata pencaharian penduduk, terdiri dari yang menurut mitos merupakan pemberian dari Dewi Sri dan 'harjo' yaitu raharjo atau sejahtera, yang berarti desa yang sejahtera dengan mata pencaharian pokok warganya bercocok tanam (Anonim, 2021). Posisi desa yang dikelilingi sungai Oya dan Sungai Opak serta berada di lembah membuat suasananya menjadi indah dan menarik, sehingga pemerintah desa berkeinginan mengembangkanya sebagai desa wisata. Selain wisata potensi sumber daya alam desa Sriharjo terbesar pada sektor pertanian dan peternakan, tetapi pengelolaan pertanian, khususnya peternakan masih tradisional. Ternak yang banyak dipelihara oleh masyarakat desa Sariharjo adalah domba sebagai tabungan dengan memanfaatkan halaman ataupun pekarangan dekat rumah untuk kandang dengan lantai tanah. Limbah ternak domba belum dimanfaatkan secara optimal untuk pupuk dan beberapa dibuang di sekitar kandang atau dialirkan ke sungai. Keberadaan kandang lantai tanah di dekat rumah penduduk ini perlu dievaluasi berkaitan dengan program pemerintah desa Sriharjo berupaya mengembangkan potensi desa melalui desa Wisata berbasis pertanian guna untuk meningkatkan kesejahteraan warganya.

Kandang merupakan salah satu syarat yang sangat penting di dalam usaha peternakan, termasuk domba (Hurriyyah et al., 2019). Kandang berfungsi untuk memberikan perlindungan domba dari radiasi matahari dan paparan suhu yang terlalu ekstrim sebagai salah satu upaya pemeliharaan produktivitas dan kesejahteraan domba (Caroprese, 2008). Kandang yang dibangun berada di dekat rumah penduduk, kemungkinan akan menimbulkan permasalahan terutama estetika dan kesehatan lingkungan akibat adanya pencemaran bahan dan bau yang berasal dari limbah ternak. Menurut Caroprese (2008) limbah ternak akan memengaruhi kesehatan lingkungan. Lingkungan yang bersih dapat menurunkan paparan mikroorganisme pathogen yang merugikan hewan ternak. Selain dapat menyebabkan ternak menjadi sakit bahkan kematian, paparan mikroorganisme pathogen dapat menurunkan kualitas daging dan menurunkan produktivitas susu yang dihasilkan.

Desa Sriharjo saat ini mulai dikembangkan menjadi desa wisata agro dan sudah mulai banyak wisatawan khususnya para pesepeda hadir untuk menikmati suasana pedesaan. Permasalahan timbul ketika banyak peternak membuang kotoran ternaknya di sungai dekat lokasi wisata, sehingga membuat pencemaran air, lingkungan, bau dan kemungkinan penularan penyakit. Di sisi lain, usaha peternakan di desa Sriharjo telah ada kelompok ternak yang dimotori oleh pemuda, tetapi para pemuda ini belum memiliki pengetahuan dan pengalaman mengenai pengelolaan usaha dan budidaya ternak domba sehat terpadu. Oleh karena itu, melalui program PKM berbasis pengembangan Desa binaan, salah satu tim dari Direktorat Pengabdian Kepada Masyarakat 
Universitas Gadjah Mada melakukan pendapingan penataan usaha peternakan yang dimulai dengan pembuatan percontohan kandang domba sehat secara komunal. Tujuan dari pengabdian kepada masyarakat ini adalah melakukan pendampingan pembuatan kandang percontohan dalam rangka usaha peternakan domba sehat di Desa Sriharjo, Kecamatan Imogiri, Kabupaten Bantul. Keberhasilah pembuatan kandang ini akan berdampak terhadap pola pemeliharaan ternak domba yang lebih sehat, minimal di wilayah tersebut.

\section{METODE}

Kegiatan ini dilaksanakan pada Mei 2020 - Juli 2021 di Kelompok Ternak Taruna Tani Hijaunya Cinta, Desa Sriharjo, Kecamatan Imogiri, Kabupaten Bantul. Sebanyak 30 peternak telah terlibat di dalam kegiatan PKM ini. Kegiatan dimulai dengan sosialisasi, penyuluhan dan pendampingan berkaitan dengan kandang sehat dengan metode mengacu kegiatan PKM sebelumnya (Indarjulianto et al., 2021). Beberapa peternak diajak studi banding di salah satu peternakan di Yogyakarta untuk melihat kandang domba sehat yang sudah ada. Berdasarkan studi banding, selanjutnya peternak didampingi merealisasikan pembuatan kandang domba sehat secara gotong royong. Kandang yang telah dibangun selanjutnya diserahkan kepada kelompok ternak dan pemerintah desa Sriharjo untuk digunakan secara maksimal.

Pemahaman masyarakat terhadap kandang domba sehat diukur melalui wawancara dan pengisian kuesioner sebelum dan sesudah pelaksanaan PKM. Hasil PKM di lapangan dan wawancara dianalisis dan disajikan secara deskriptif.

\section{HASIL DAN PEMBAHASAN}

Sebelum PKM, kandang domba yang ada semuanya didirikan di dekat rumah dengan pengelolaan yang tradisonil, dengan pembuangan limbah di sekitar kandang atau dialirkan ke parit menuju sungai (Gambar 1A). Kondisi ini tidak jauh berbeda dengan kebanyakan peternak skala kecil di Indonesia, seperti yang ditemukan pada peternakan di Desa Ngesrep Balong, Kecamatan Limbangan, Kabupaten Kendal Provinsi Jawa Tengah dan di Kecamatan Samigaluh, Kabupaten Kulon Progo (Nugrogo et al., 2018; Prabowo dan Widodo, 2021). Kandang yang berada di dekat rumah tidak dianjurkan karena kemungkinkan dapat menyebabkan timbulnya penyakit termasuk dapat menularkan penyakit ke manusia. Selain itu, sisa pakan dan kotoran ternak dapat menimbulkan pencemaran berupa bau yang tidak sedap, serta memberikan estetika yang kurang sedap (Nugroho et al., 2018). Kotoran ternak berkontribusi sekitar 57-76\% menciptakan lingkungan yang menguntungkan bagi perkembangan mikroorganisme pathogen. Kotoran ternak juga menjadi media pertumbuhan bakteri Salmonella sp. yang mempengaruhi kualitas daging maupun ternak 
(Woldermariam et al., 2005). Selain salmonellosis, salah satu penyakit yang dapat menular dari hewan ke manusia melalui limbah peternakan adalah helmintiasis (Pestechian et al., 2014).
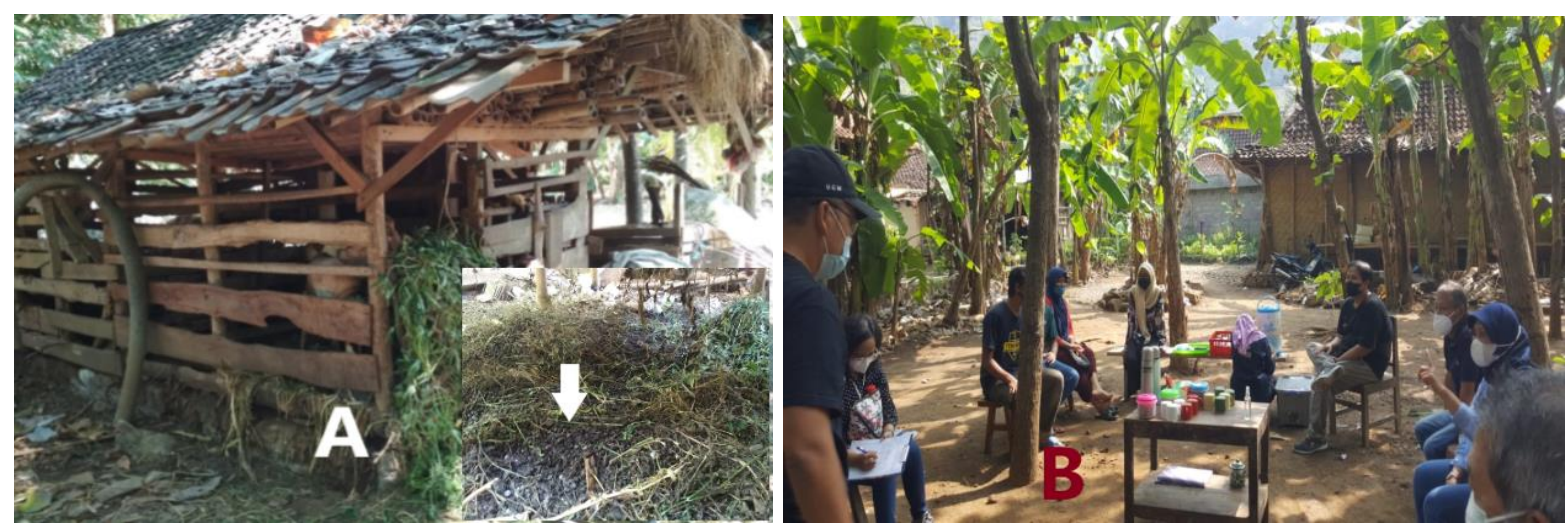

Gambar 1. A: Contoh kandang tradisional dan lokasi pembuangan limbah peternakan (tanda panah). B: Situasi penyuluhan di saat pandemi Covid-19.

Sosialisasi dan penyuluhan tentang kandang domba sehat telah berhasil dilaksanakan. Sosialisasi dan penyuluhan lanjutan berkaitan dengan pemanfaatan kandang dilakukan secara luring dengan mengikuti protokol kesehatan dalam rangka memutus siklus covid-19 (Gambar 1B). Protokol Kesehatan (prokes) yang dilaksanakan mengikuti anjuran kemenkes antara lain 1) membersihkan tangan secara teratur dengan cuci tangan pakai sabun dan air mengalir selama 40-60 detik atau menggunakan cairan antiseptik berbasis alkohol (handsanitizer) minimal $20-30$ detik; 2) Menggunakan alat pelindung diri berupa masker yang menutupi hidung dan mulut; 3) Menjaga jarak minimal 1 meter dengan orang lain (Anonim, 2020). Pada saat pelaksaan penyuluhan, prokes ini telah dapat dilaksanakan dengan baik terutama penggunaan masker dan mencuci tangan dengan antiseptik. Sambodo et al. (2020) melaporkan bahwa realisasi prokes yang paling sulit pada kegiatan PKM penyembelihan hewan kurban terutama adalah "jaga jarak" dengan orang lain. Penyuluhan ataupun pelatihan sangat penting dilakukan, agar masyarakat dapat mengerti dan termotivasi merealisasikan suatu rencana, dalam hal ini pembuatan kandang domba sehat.

Pengelolaan limbah peternakan yang baik akan membantu pemutusan siklus penularan penyakit-penyakit tersebut. Pemutusan siklus tersebut di peternakan desa Sriharjo dapat ditanggulangi salah satunya dengan merubah lantai kandang dari lantai tanah menjadi panggung yang didesain sehingga kotoran langsung turun ke bak penampungan di bawah kandang. Menurut Suherman dan Kurniawan (2017) perkandangan sistem panggung mempunyai kelebihan, karena dapat memudahkan pengambilan kotoran ternak yang berada di bawah kandang tanpa mengganggu ternaknya. Purwaningsih et al. (2017) menyatakan bahwa sistim pemeliharaan menggunakan kandang model panggung menjauhkan ternak dari kontak dengan telur infektif yang keluar bersama feses. Larva cacing ini secara teoritis dapat menginfeksi ternak di kandang atau bahkan auto-infeksi 
karena telur cacingnya sudah berisi larva dan cepat sekali menetasnya. Oleh karena itu, untuk menghindari adanya pengaruh terhadap kesehatan lingkungan, domba dan manusia, maka sebaiknya kandang dibangun tidak terlalu dekat dengan rumah masyarakat. Hal ini telah disosialisasikan kepada peternak di desa Sriharjo dan mereka telah merealisasikannya, setelah melihat gambaran nyata pada saat studi banding.

Dalam rangka untuk memberikan gambaran nyata tentang kandang ternak sehat, peternak telah melakukan studi banding ke suatu peternakan kambing di wilayah Yogyakarta. Kegiatan ini telah memberikan semangat kepada peternak untuk merealisasikan kandang sehat komunal. Studi banding ini sangat diperlukan, karena telah memberikan visualisasi/pembelajaran langsung kepada peternak. Motode pemberdayaan masyarkat melalui studi banding juga telah dilakukan oleh Saugi dan Sumarno (2015) dengan hasil yang memuaskan. Hasil studi banding telah dibuat sketsa kandang dan direalisasikan dengan pembuatan kandang sehat komunal di tanah kas desa yang lokasinya masih di desa Sriharjo, tetapi tidak terlalu dekat dengan hunian masyarakat (Gambar 2). Kandang percontohan tersebut dibuat sistim panggung yang diberi penampungan kotoron di bawahnya, sehingga kotoran tidak mencemari lantai dan sekaligus dapat dengan mudah dimanfaatkan ataupun diolah menjadi pupuk organik. Kandang yang dibuat di desa Sriharjo ini dibuat sebagai kandang komunal yang didesain supaya kotoran/limbah dapat dengan mudah ditampung untuk dibuat pupuk organik, serta disesuaikan dengan iklim di daerah tersebut. Nugroho et al. (2018) telah melakukan pengabdian mendampingi pembuatan kandang sehat berdasarkan "Bioclimat", yaitu bangunan kandang yang bersinergi dengan kondisi iklim lingkungan.

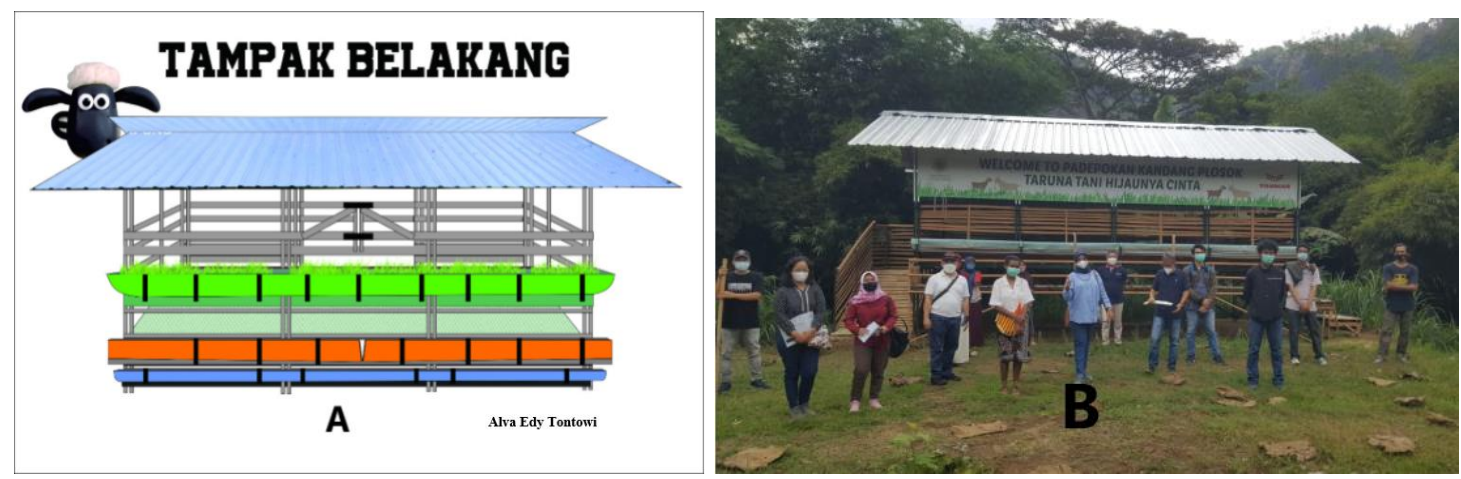

Gambar 2. A. Desain kandang; B. Kandang domba hasil pendampingan

Berdasarkan survey sebelum pelaksanaan PKM masih sangat sedikit peternak yang mengerti tentang kandang sehat, tetapi semua peternak dapat mengerti setelah pelaksanaan PKM (Tabel 1). Sedikitnya peternak yang mengerti tentang kesehatan ternak sebelum pelaksanaan PKM kemungkinan karena kebanyakan peternak sebelumnya tidak pernah memelihara domba. Menurut Wesa dan Suryono (2014), pelatihan dapat meningkatkan sumber daya manusia (SDM), membangkitkan semangat untuk berkoperasi dan berwirausaha. 
Tabel 1. Hasil survey pengetahuan peternak tentang kandang domba sehat $(n=30)$

\begin{tabular}{clcc}
\hline \multirow{2}{*}{ No } & & Aspek yang dinilai & \multicolumn{2}{c}{ Persentase (\%) } \\
\cline { 3 - 4 } & & $\begin{array}{c}\text { Sebelum } \\
\text { PKM }\end{array}$ & $\begin{array}{c}\text { Setelah } \\
\text { PKM }\end{array}$ \\
\hline 1 & Pengetahuan tentang istilah peternakan domba sehat & 0 & 100 \\
2 & Pengetahuan manfaat adanya peternakan domba sehat & 10 & 100 \\
3 & $\begin{array}{l}\text { Pengetahuan fungsi membawa domba ke dalam kandang } \\
\text { terpadu domba sehat }\end{array}$ & 0 & 100 \\
\hline
\end{tabular}

\section{KESIMPULAN}

Pengabdian kepada Masyarakat ini disimpulkan bahwa kandang ternak domba telah berhasil dibangun dan fungsinya telah dimengerti oleh semua peternak di desa Sriharjo.

\section{UCAPAN TERIMA KASIH}

Kegiatan ini didanai oleh YESSA tahun 2020 dan Direktorat Pengabdian Kepada Masyarakat Universitas Gadjah Mada melalui skema "Program Pengabdian Kepada Masyarakat Berbasis Desa Binaan” Tahun 2021, dengan nomer kontrak 315/UN1/DPM/YANMAS/PM/2021.

\section{DAFTAR PUSTAKA}

Anonim. 2020. Pedoman Pencegahan Dan Pengendalian Coronavirus Disesase (COVID-19).

Kementerian Kesehatan RI, Revisi ke 5. https://infeksiemerging.kemkes.go.id/download/REV05_Pedoman_P2_COVID-19_13_Juli_2020_1.pdf. diakses 16-08-2021.

Anonim. 2021. Sejarah Kelurahan Sriharjo. https://sriharjo.bantulkab.go.id/first/artikel/2. diakses 07-08-2021.

Caroprese, M. 2008. Sheep Housing and Welfare. Small Ruminant Research. 76: 21-25.

Hurriyyah, Z., Latsuti, N.D.R., dan Nangoi, L. 2019. The Correlation between Goat Maintenance Management to the Incidence of Gastrointestinal Parasite Infections. Indian Journal of Public Health Research \& Development. 10(9): 415-419.

Indarjulianto S, Widiyono I, Sarmin, dan Airin CM. 2021. Pelatihan Penggunaan Alat Penghalus Kotoran Ternak di Kelompok Ternak Sidomaju Bantul Yogyakarta. 2021. IGKOJEI: Jurnal Pengabdian Masyarakat. 2(1): 32 - 37. DOI: https://doi.org/ 10.46549/igkojei.v2i1.168.

Nugroho, A.S. Endah Rita Sulistya Dewi, E.R.S., dan Rosyida, R. 2018. Ternak Domba Menuju Desa Mandiri Pangan Berdasarkan "Bioclimat" Di Desa Ngesrep Balong. Jurnal DIANMAS. 7(1): 51-58.

Pestechian, N., Kalani, H., Faridnia, R., Yousefi, H.A. 2014. Zoonotic Gastrointestinal Nematodes (Trichostrongylidae) from Sheep and Goat in Isfahan, Iran. Acta Scientiae Veterinariae. 42(1): $1-6$.

Prabowo, T.A., dan Widodo, A.S. 2021. Karakteristik Peternakan Kambing Di Kawasan Perbukitan Menoreh: Studi Kasus Di Kecamatan Samigaluh Kabupaten Kulon Progo. Bulletin of Applied Animal Research. 3(1).

Purwaningsih, Noviyanti, dan Sambodo, P. 2017. Infestasi Cacing Saluran Pencernaan Pada Kambing Kacang Peranakan Ettawa di Kelurahan Amban Kecamatan Manokwari Barat Kabupaten Manokwari Provinsi Papua Barat. Jurnal Ilmiah Peternakan Terpadu. 5(1): 8 - 12.

Sambodo, P., Widayati, I., Nurhayati, D., Baaka,A. Arizona, R. 2020. Pemeriksaan Status Kesehatan Hewan Kurban Dalam Situasi Wabah Covid-19 Di Kabupaten Manokwari. IGKOJEI: Jurnal Pengabdian Masyarakat. 1(1): 7 -13.

Saugi, W. dan Sumarno. 2015. Pemberdayaan Perempuan Melalui Pelatihan Pengolahan Bahan Pangan Lokal. Jurnal Pendidikan dan Pemberdayaan Masyarakat. 2(2): 226 - 238. 
Suherman, dan Kurniawan, E. 2017. Manajemen Pengelolaan Ternak Kambing Di Desa Batu Mila Sebagai Pendapatan Tambahan Petani Lahan Kering. Jurnal Dedikasi Masyarakat. 1 (1): 7 13.

Wesa, A., dan Suryono, Y. (2014). Kesejahtera-an ekonomi masyarakat peserta pelatihan kelompok prakoperasi di Kecamatan Namlea Kabupaten Buru. Jurnal Pendidikan dan Pemberdayaan Masyarakat. 1(2): 149 -159.

Woldermariam, E., Molla, B., Alemayehu, D. dan Muckle, A. 2005. Prevalence and Distribution of Salmonella in Apparently Healthy Slaughtered Sheep and Goats in Debre Zeit, Ethiopia. Small Ruminant Research. 58: 19-24. 